\title{
Studies on chaetognaths off Ubatuba region, Brazil. II. Feeding habits
}

\author{
Tsui Hua LIANG \& Luz Amelia VEGA-PÉREZ \\ Instituto Oceanográfico da Universidade de São Paulo \\ (Caixa Postal 66149, 05389-970 Sāo Paulo, SP, Brasil)
}

- Abstract: The diet of chaetognath species were studied by examining the gut contents of 9466 specimens collected off Ubatuba region, São Paulo State. The greatest proportion of chaetognaths (7119 individuals) showed their gut contents empty. Copepods, mollusc eggs, appendicularians, cladocerans and annelids were the most common food items in the gut contents of juveniles and mature stages. Cannibalism occurred in low frequency. In Summer the copepods Temona stylifera and Paracalanus spp were more abundant, whereas Oncaea spp and mollusc eggs were heavily preyed in Winter. There was a clear trend of increasing prey size with the developmental stage.

- Resumo: O estudo dos hábitos alimentares das espécies de Chaetognatha foi realizado a partir da análise do trato digestivo de 9466 indivíduos dos estágios 0 IV. Os quetógnatos foram coletados ao largo da regiāo de Ubatuba, Estado de São Paulo, com o auxílio da rede Bongo (Malha 0,200 mm e 0,303 mm), nos verōes de 1985 - 1987 e invernos de 1986 e 1987. Dos 9466 tratos digestivos analisados, 7119 estavam vazios e 2347 apresentaram de 1 a 3 presas. Grande quantidade de material amorfo e semi-digerido também foram detectados. A dieta esteve constituída basicamente de copépodos (Calanoida e Poecilostomatoida), cladóceros, ovos de moluscos, náuplios de crustáceos, apendiculárias e poliquetos, entre outros. O canibalismo foi observado a partir do estágio I, porém com baixa frequência. Os estágios jovens (0-I) mostraram preferência por presas de tamanho pequeno como náuplios e copépodos do gênero Oncaea, enquanto que os estágios maduros por presas maiores como Temora stylifera, Corycaeus sp e Eucalanus pileatus.

- Descriptors: Feeding, Predation, Zooplankton, Chaetognatha, S. enflata, S. friderici, S. hispida, Ubatuba, Brazil, South Atlantic.

- Descritores: Alimentação, Predação, Zooplâncton, Chaetognatha, S. enflata, S. friderici, S. hispida, Ubatuba, Brasil, Atlântico Sul.

\section{Introduction}

The interest in the feeding of zooplankton has increased considerably during recent years. Behavioral responses to food species, concentration and their trophic interactions have been studied for many years in an attempt to elucidate fundamental patterns structuring plankton communities (Gallager, 1988).

Zooplankton plays a critical role in the ecology of marine systems by serving as a link between phytoplankton, bacterioplankton and higher trophic levels in the nekton and benthos. An understanding of marine planktonic food webs requires information on the abundance, biomass and rate of interactions between all trophic levels (Buskey, 1993).

Studies on feeding have been focused mainly on the herbivorous organisms like copepods while carnivorous species have been neglected. According to Gallager (1988) the importance of studying predator feeding mechanisms is that we can predict how carnivorous zooplankton will affect community structure and function by indirectly measuring feeding behavior, e. g., gut content analyses or counts of available prey items.

Chaetognaths are known as one of the most important and active predators of zooplankton, preying upon a wide variety of organisms (Raymont, 1983; Alvariño, 1985). They may affect the distribution, density and occurence of their preys (Cheney, 1985).

In Brazilian waters, many studies on chaetognaths have examined their systematics, distribution and occurrence (Vannucci \& Hosoe, 1952; Almeida-Prado, 1961a, b; 1968; Ferreira da Costa, 1970; Coelho, 1993). The knowledge of their feeding habits has received little attention, being limited to the study of the chaetognath $S$. friderici off Ubatuba (Vega-Pérez \& Liang, 1992). 
The aim of the present study is to analyse the qualitative and quantitative food composition of the chaetognath species collected off Ubatuba region.

\section{Material and methods}

This study was part of a program of multidisciplinary study of tropical marine ecosystems: "Brazilian Coastal Ecosystems", off Ubatuba region, Sāo Paulo State, from 1985 to 1989.

Zooplankton samples studied in this work were collected on five oceanographic cruises during December 1985, 1986, 1987 and July 1986, 1987. A survey grid of 30 standard plankton stations distributed along six transects was established in the sea frontal to the Ubatuba region $\left(24^{\circ} 10^{\prime} \mathrm{S}-44^{\circ} 30^{\prime} \mathrm{W}\right.$ and $\left.23^{\circ} 30^{\prime} \mathrm{S}-45^{\circ} 20^{\prime} \mathrm{W}\right)$.

Oblique hauls were made with a Bongo net fitted with a finer $(0,200 \mathrm{~mm})$ and a coaser meshed net $(0,303 \mathrm{~mm})$, and provided with flowmeters. Samples were preserved in a seawater solution of $10 \%$ buffered formalin. In this study, only samples obtained by regular mesh size were analysed.

Temperature and salinity data of the water column were obtained simultaneously with the use of Nansen bottles.

In the laboratory, plankton was subsampled with the cylindrical Motoda Splitter (Omori \& Ikeda, 1984). All the chaetognath specimens were removed from the subsamples and identified accordingly to Almeida-Prado (1961a) and Alvariño (1969). The maturity stages were determined based on Reeve (1970): (0-II) young stages; (III-IV) adult stages.

Gut content of 9466 specimens were examined by body transparency (Pearre, 1980) and the prey items were identified to species or to the lowest taxonomic level possible using a stereoscopic microscope (Wild M7).
Well-digested food was called unidentificd. Copepods were identified based on Björnberg (Boltovskoy, 1981).

Percentage number was used as an index of the importance of each prey item in the diet. Similarities of the diet were calculated using the Schoener index (1968) wich measures the overlap between two categories of comparison and gives values from 0 (no overlap) to 1 (complete overlap):

$$
\mathrm{D}=1-0,5\left[\sum_{\mathrm{i}=1}^{\mathrm{n}} \text { (Pxi - Pyi) }\right]
$$

were Pxi is the proportion of food category in the diet of species $\mathrm{x}, \mathrm{Pyi}$ is the proportion of food category in the diet of species $y$, and $\mathrm{n}$ is the number of food categories. Biologically, overlap is considered significant when the value exceeds 0,60 (Zaret \& Rand, 1971; Wallace, 1981).

\section{Results}

The analysis of the gut contents of 9466 chaetognaths off Ubatuba region showed a total of 7119 specimens with empty guts and 2347 containing 1 to 3 preys (Table 1). The bulk of chaetognath specimens contained only one prey. Multiple preys (2 - 3) were found in S. enflata (129), S. hispida (24), S. friderici (16) and S. tenuis (4).

Chaetognath species preyed upon a wide variety of organisms. The food organisms most frequently found in their guts were crustaceans, mollusc eggs, appendicularians and polychaetes. In all cases, however, the most important prey within the global diet were the copepods, specially Calanoida and Poecilostomatoida. Cannibalism was observed, but in low frequency mostly in $S$. enflata, $S$. hispida and $S$. friderici. This behavior was detected in stage $I$ and tended to increase in the later stages.

Table 1. Number of chaetognath species analised; $P=$ No. of specimens with prey items; $E=$ No. of specimnens with empty guts

\begin{tabular}{|c|c|c|c|c|c|c|c|c|c|c|c|c|c|c|c|c|c|c|c|c|}
\hline \multirow[b]{2}{*}{ CRUISE } & \multicolumn{2}{|c|}{ S. enflata } & \multicolumn{2}{|c|}{$S$. friderici } & \multicolumn{2}{|c|}{ S. hispida } & \multicolumn{2}{|c|}{$S$. tenuis } & \multicolumn{2}{|c|}{$S$. minima } & \multicolumn{2}{|c|}{$\mathcal{K}$ pacifica } & \multicolumn{2}{|c|}{$S$ S serratodenta } & \multicolumn{2}{|c|}{$S$. bipunctata } & \multicolumn{2}{|c|}{ S. hexaptera } & \multicolumn{2}{|c|}{ P. draco } \\
\hline & E & $P$ & $E$ & $P$ & E & $P$ & E & $P$ & E & $\mathbf{P}$ & E & P & E & P & E & P & E & $p$ & E & $P$ \\
\hline SUNER/1985 & 236 & 56 & 242 & 85 & 78 & 14 & 26 & 17 & 14 & 9 & 28 & 4 & 21 & 24 & 47 & 2 & . & . & 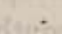 & - \\
\hline WINTER/1986 & 1021 & 470 & 326 & 80 & 96 & 129 & 2 & 20 & 42 & 9 & 154 & 28 & 2 & . & 0 & 2 & . & - & - & - \\
\hline SUMAER/1986 & 711 & 135 & 387 & 70 & 278 & 98 & 19 & 45 & 21 & 1 & 8 & 4 & 15 & 19 & 2 & - & 2 & 1 & 4 & - \\
\hline UINTER/1987 & 1845 & 658 & 919 & 123 & 108 & 96 & 16 & 32 & 179 & 8 & 100 & 18 & 9 & 1 & . & - & 2 & - & 4 & - \\
\hline SUMER/1987 & 84 & 56 & 27 & 26 & 16 & 6 & - & - & 14 & 0 & 5 & 1 & 6 & - & - & - & * & . & 3 & - \\
\hline TOTAL & 3897 & 1375 & 1901 & 384 & 576 & $3 / 43$ & 63 & 114 & 270 & 27 & 295 & 55 & 53 & 44 & 49 & 4 & 4 & 1 & 11 & 0 \\
\hline
\end{tabular}


Large quantities of well-digested food and considerably high number of unidentified preys were also detected in the gut contents of the chaetognaths.

The prey diversity generally changed with the developmental stage and the seasons. Older stages (II-IV) consumed higher diversity of preys than the younger stages (0-I). Similar results were observed in the Winter surveys when chaetognaths showed higher diversity of food than specimens collected in the Summer.

Only the diet of $S$. enflata, $S$. friderici and $S$. hispida will be detailed, because the other species were not present in enough number of individuals.

\section{S. enflata}

Copepods dominated the diet of $S$. enflata. Mollusc eggs, crustacean nauplii, cladocerans and appendicularians were also particulary important in the diet of this species (Table 2).

Table 2. Number of chaetognath species analised;

$\mathrm{P}=$ No. of specimens with prey items; $E=$ No.

of specimens with empty guts; $T=$ total number of individuals

\begin{tabular}{|c|c|c|c|}
\hline Food items & S. enflata & S. friderici & S. hispida \\
\hline \multicolumn{4}{|l|}{ CRUSTACEA } \\
\hline COPEPODA & & & \\
\hline CALANOIDA & 19 & 3 & 6 \\
\hline Calanoides carinatus & 4 & & 2 \\
\hline Nannocalanus minor & 2 & 1 & \\
\hline Eucalanus sewelli & & & 1 \\
\hline E. pileatus & 8 & 2 & \\
\hline Paracalanus sp & 12 & 12 & 3 \\
\hline P. quasimodo & 11 & 4 & 3 \\
\hline Clausocalanus furcatus & 28 & 3 & 2 \\
\hline C. arcuicomis & 17 & 1 & 3 \\
\hline Ctenocalamus sp & 1 & 1 & \\
\hline Calocalanus styliremis & 1 & & \\
\hline Candacia curta & & & 1 \\
\hline Scolecithricella vitatta & 1 & 1 & \\
\hline Scolecithricella bradyi & & 2 & \\
\hline Calanopia americana & 3 & 1 & \\
\hline Temora stylifera & 91 & 27 & 20 \\
\hline Centropages velificatus & 5 & & 1 \\
\hline Euchaeta marina & 1 & & \\
\hline Pleurommama sp & 1 & & \\
\hline $\begin{array}{l}\text { Pontellopsis sp } \\
\text { CYCLOPOIDA }\end{array}$ & 2 & & \\
\hline Oithona sp & 1 & & \\
\hline $\begin{array}{l}\text { O. plumifera } \\
\text { O. nana }\end{array}$ & & & \\
\hline POECILOSTOMATOIDA & A & & \\
\hline Saphririna angusta & 1 & 1 & \\
\hline Oncaea conifera & 6 & & \\
\hline O. venusta & 66 & 7 & 18 \\
\hline O. curta & 32 & 2 & 17 \\
\hline $\begin{array}{l}\text { O. subtilis } \\
\text { O. mediterranea }\end{array}$ & 4 & 1 & \\
\hline Oncaea sp & 135 & 21 & 14 \\
\hline Corycaeus sp & 3 & 6 & 2 \\
\hline
\end{tabular}

$\begin{array}{lll}\text { Food items } & \text { S. enflata S. friderici S. hispida }\end{array}$

\begin{tabular}{lrrr}
\hline C. giesbrechti & 27 & 4 & 9 \\
C. typicus & 2 & 1 & 2 \\
C. africanus & 1 & & 1 \\
C. amazonicus & 6 & & 5 \\
C. flaccus & 2 & & \\
C. limbatus & 5 & & 1 \\
Famanulla gracilis & 7 & 2 & 1 \\
HARPACTICOIDA & & & \\
Microsetella norvegica & 22 & 4 & 3 \\
Macrosetella gracilis & 9 & 3 & 1 \\
Euterpina aculifrons & 5 & 1 & \\
Unidentified & 145 & 55 & 36 \\
CLADOCERA & 12 & 3 & 1 \\
Penillia avirostris & 15 & 6 & 6 \\
Evadne spinifrons & 3 & & \\
E. tergestina & 7 & & 3 \\
Podon sp & 7 & 8 & 3 \\
OSTRACODA & 1 & & \\
AMPHIPODA & & & 1 \\
CIRRIPEDIA & 6 & & \\
DECAPODA & 1 & 1 & 1 \\
Lucifer faxoni & 2 & 32 & 26 \\
Crustacean nauplii & 50 & 10 & 8 \\
Unidentified & 15 & & \\
& & &
\end{tabular}

MOLLUSCA

Mollusca (eggs)

Gastropoda (eggs)

396
3

Pteropoda

SIPHONOPHORA

POLYCHAETHA

Polychaeta (Larvae)

6

3

UROCHORDATA

THALIACEA-Salpidae

LARVACEA

Oikopleura sp

9

2

5

1

1 3 1 36

CHAETOGNATHA
Eggs
Sagitta sp
Sagitta enflata
S. friderici
S. hispida
S. minima

Unidentified 199

$120 \quad 105$

$\begin{array}{llll}\text { Total prey items } & 1521 & 403 & 363\end{array}$

$\begin{array}{llll}\text { No. individual with preys } & 1375 & 384 & 337\end{array}$

The Shoener index of similarities showed litle or no overlap in the dict during the Summer surveys with relation to those in Winter (Table 3). In the Summer, S. enflata fed heavily on Temora stylifera, Clausocalanus sp, Corycaeus sp and Oncaea sp. Crustacean nauplii were the main food item of juvenile stages (0-I), but in the 1986 Summer the most important prey items of stage I were cladocerans, mollusc eggs, Oncaea spp. The diet of older stages (II-IV) was mainly the copepods $T$. stylifera, $C$. furcatus, Corycaeus 
sp and Oncaea spp. Appendicularians were also very frequent in the gut contents.

Table 3. Seasonal comparison of diet of three chaetognath species using index of Schoener (1968)

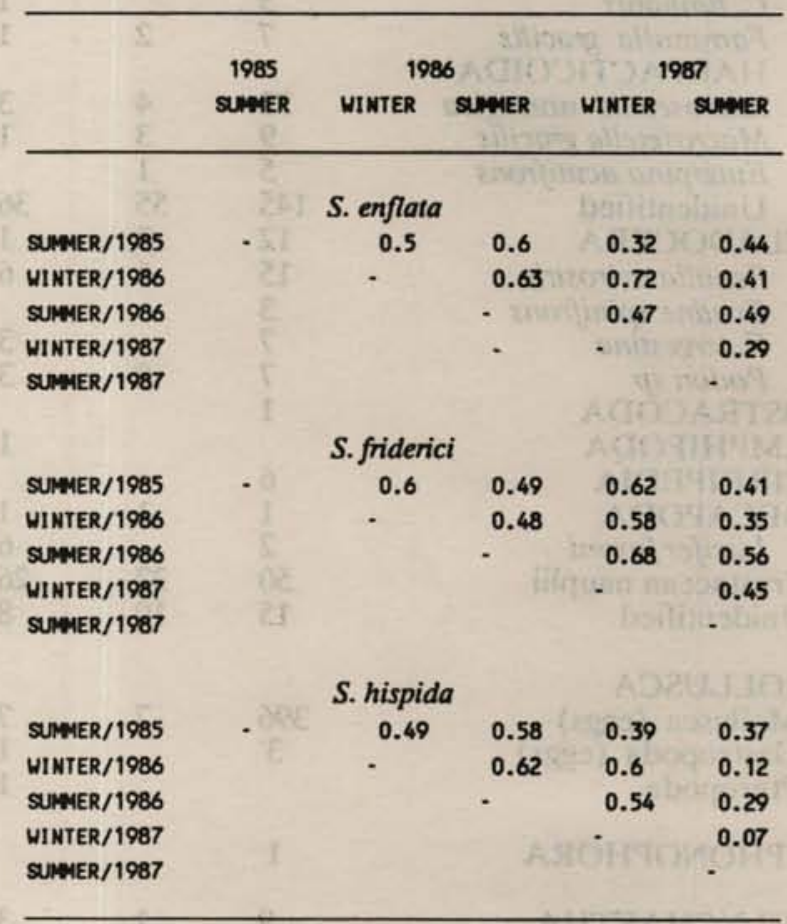

Stage I

A
In the Winter, all developmental stages of $S$. enflata preyed mostly on mollusc eggs, the copepods Oncaea spp and appendicularians. The diet of stages 0 and I were almost exclusively made up of the crustacean nauplii. Chaetognaths and appendicularians were common from stage I (Figs 1 - 3).

\section{S. friderici}

Copepods comprised the bulk of the diet of $S$. friderici. Appendicularians, crustacean nauplii and cladocerans were also found in the gut contents.

According to the Schoener index, the diet of different periods showed overlap between Summer and Winter (Table 3).

In spite of this, in the Summer the most important food items were $T$. stylifera, whereas in the Winter Oncaea spp and appendicularians were the most representative preys.

In the Summer, stages 0 and I of $S$. friderici preyed mostly on crustacean nauplii and copepods such as Oncaea spp, $T$. stylifera and Paracalanus sp. At stages II - III the diet was composed usually of appendicularians and the large sized copepods $T$. stylifera, Eucalanus pileatus and Corycaeus sp. During Winter, in all developmental stages the principal food was Oncaea spp, crustacean nauplii and

\section{Stage II}

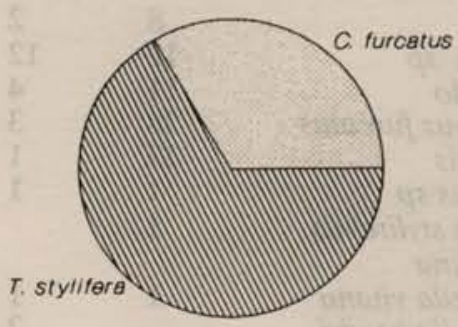

Stage IV

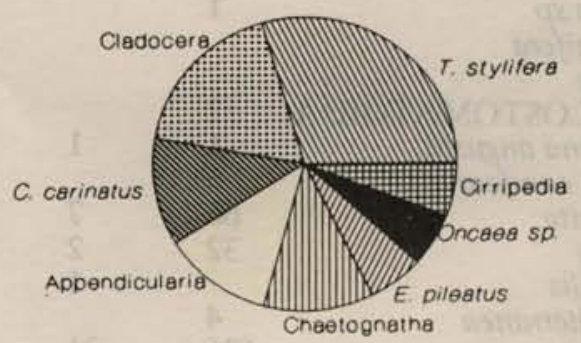

Fig. 1. Food items of $S$. enflata at each maturity stage. A-Summer 1985; B - Winter 1986. 


\section{B}

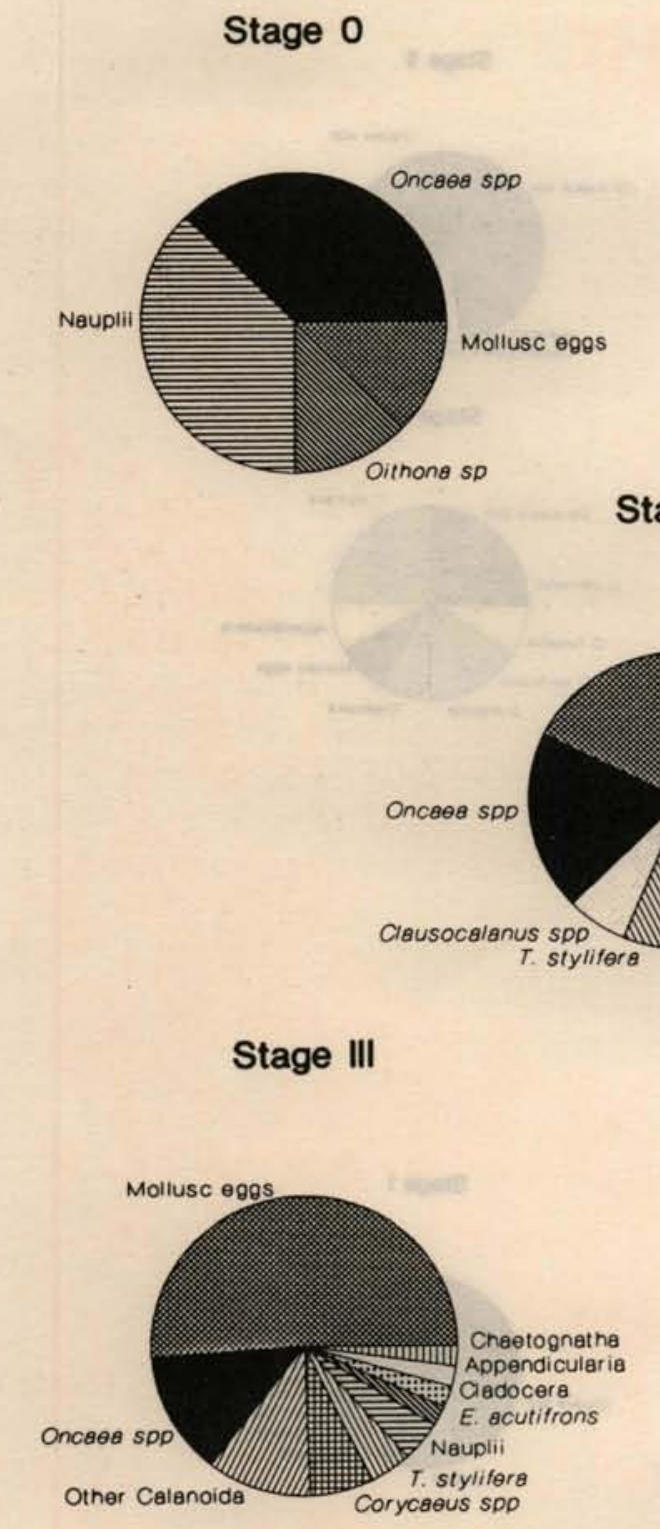

Stage II
Stage I

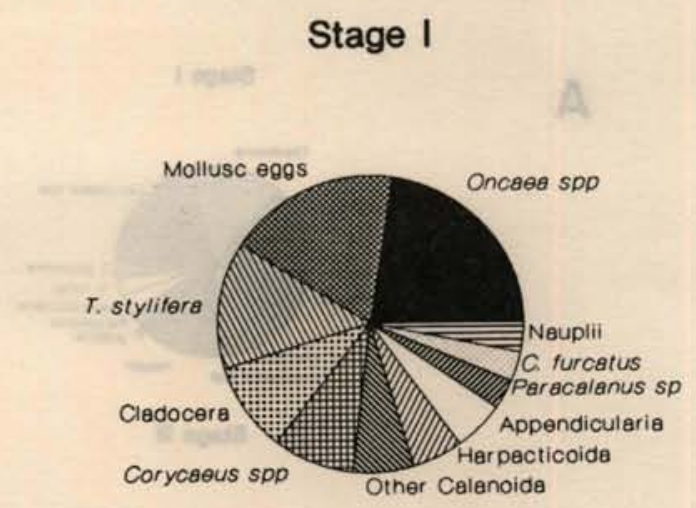

Other Calanoida

$$
\text { . }
$$


A
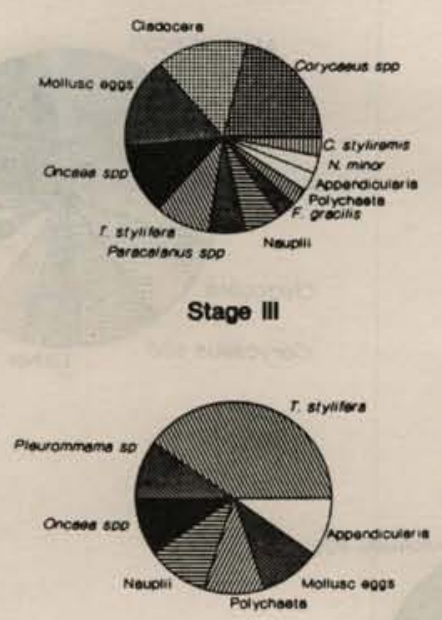

B

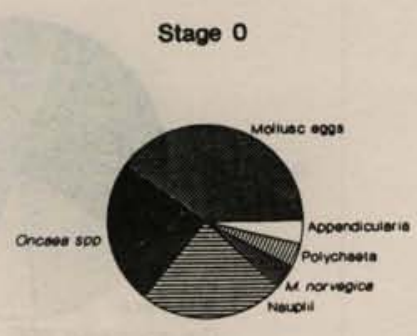

Stage II
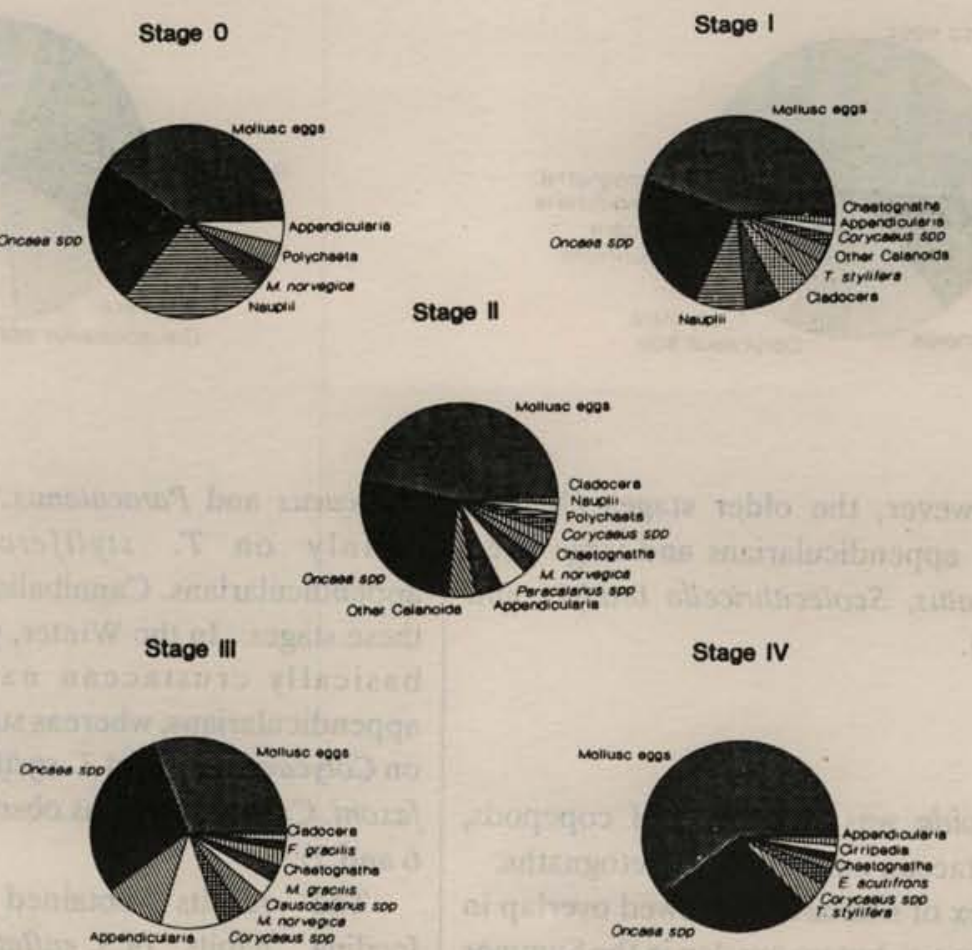

Stage II

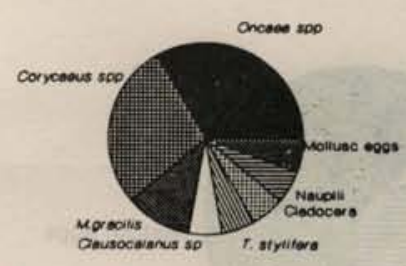

Stage IV

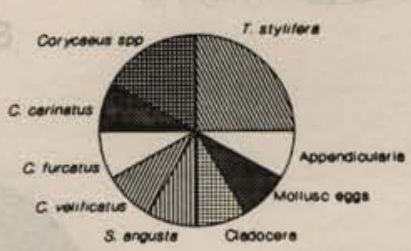

Fig. 2. Food items of S. enflata at each maturity stage. A - Summer 1986; B - Winter 1987. 
A

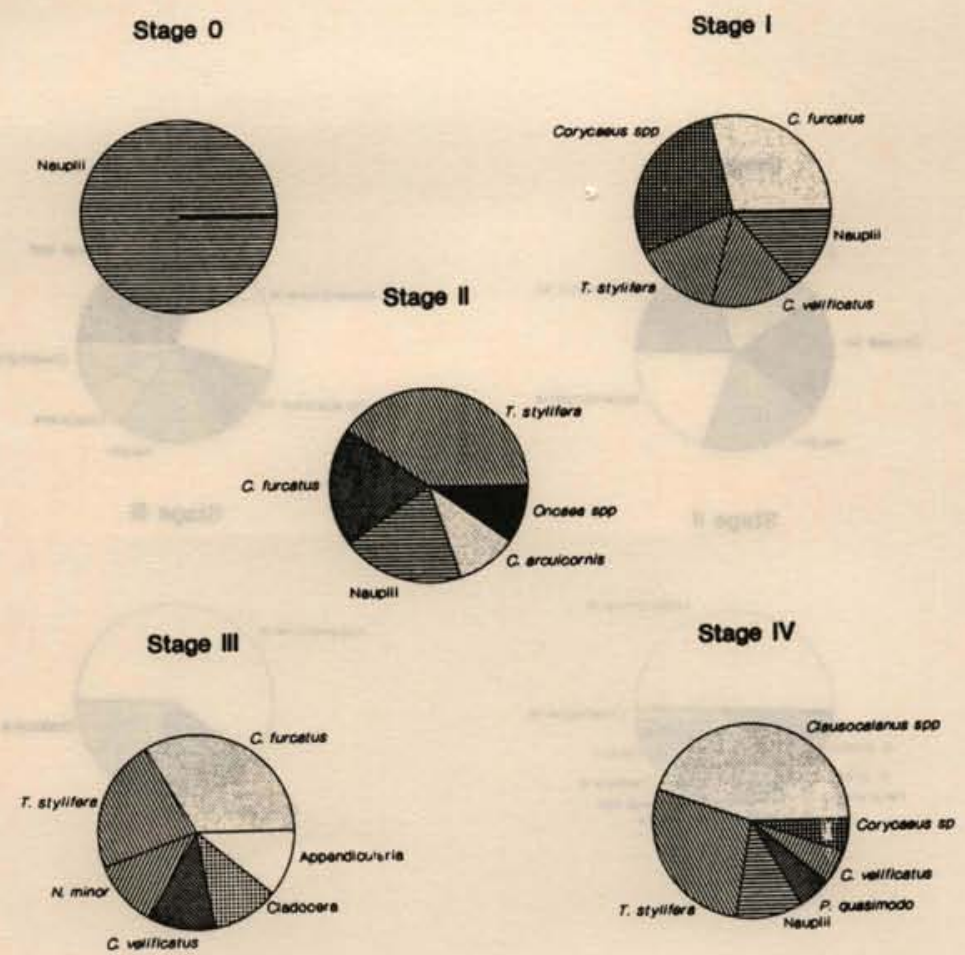

B

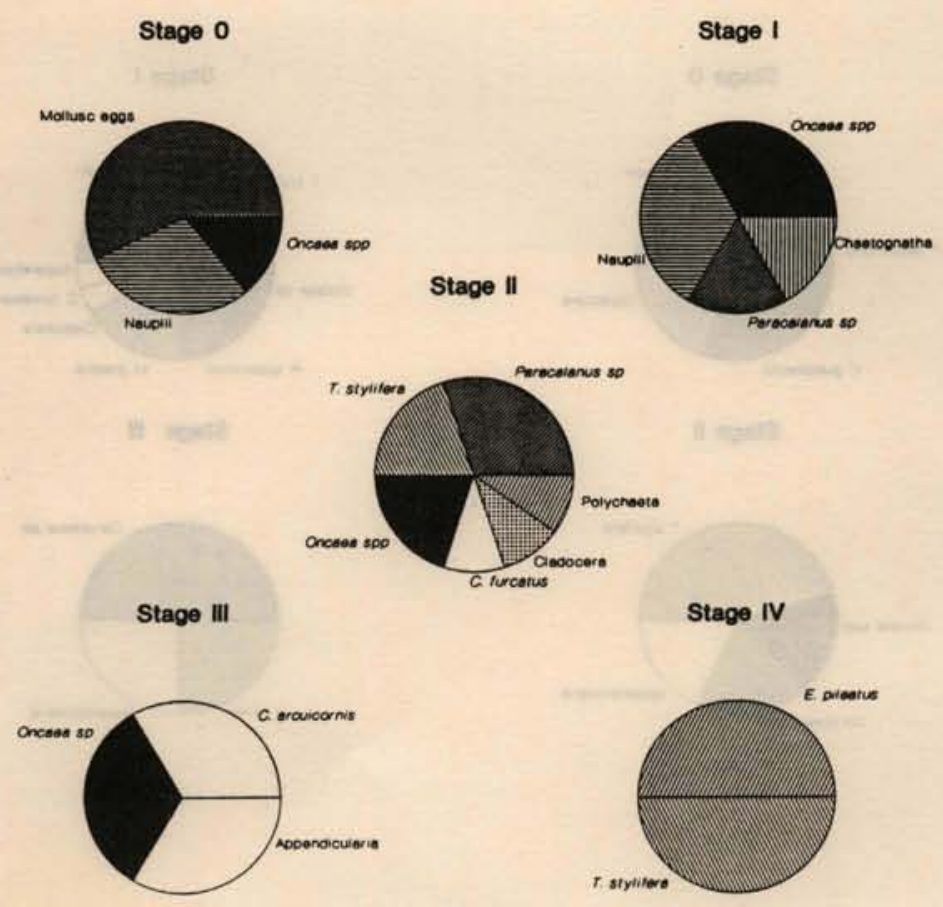

Fig. 3. Food items at each maturity stage. A-S. enflata in Summer 1987; B - S. friderici in Summer 1985. 
A

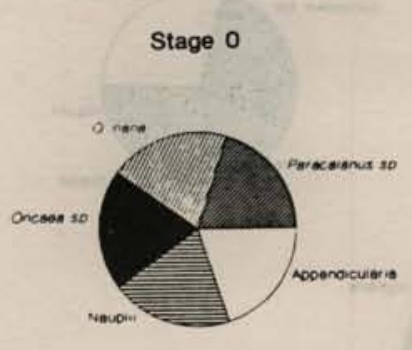

Stage II

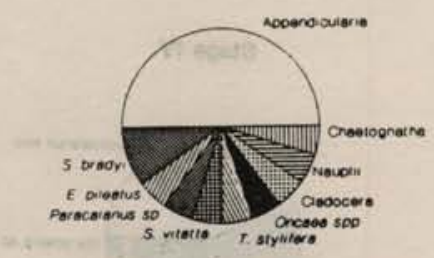

B

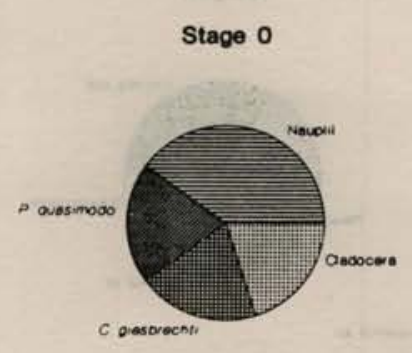

Stage II

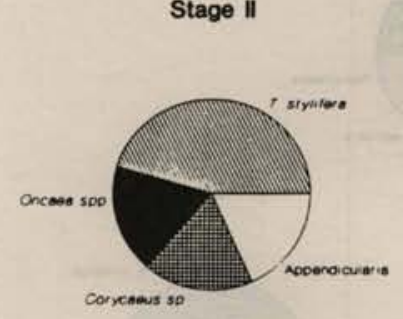

Stage I

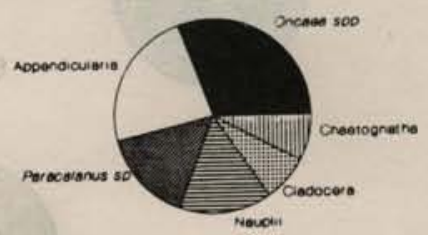

Stage III

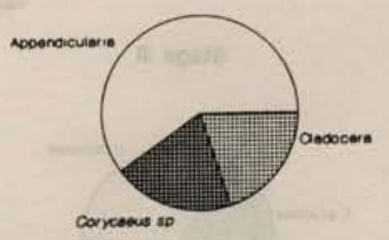

Stage I

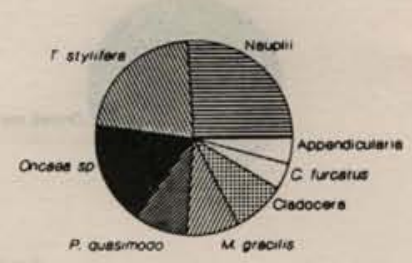

Stage III

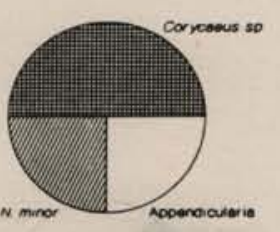

Fig. 4. Food items of S. friderici at each maturity stage. A - Winter 1986; B - Summer 1986. 
A

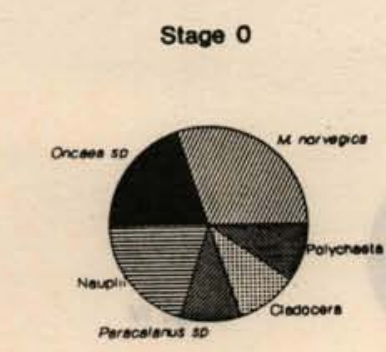

Stage II

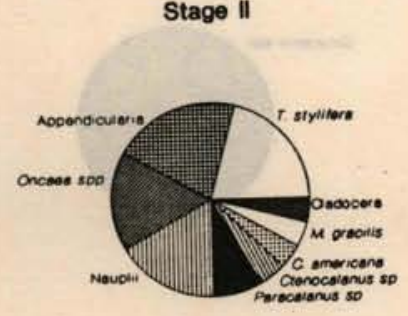

B

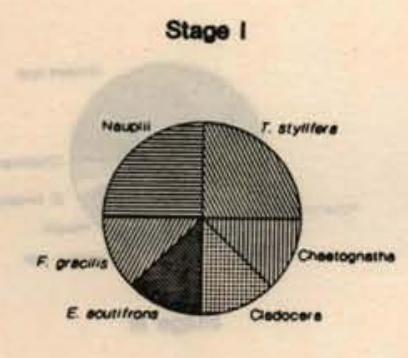

Stage III

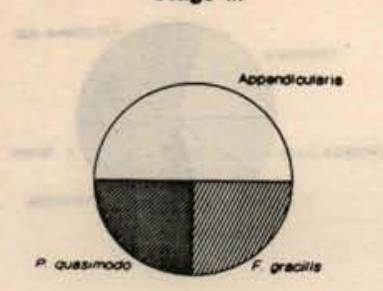

Stage I

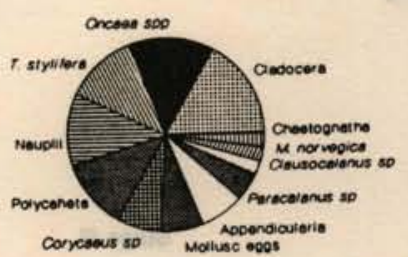

Stage III

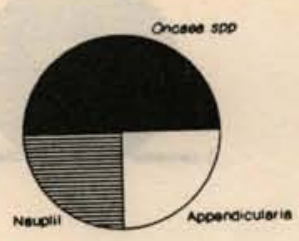

Stage \|I

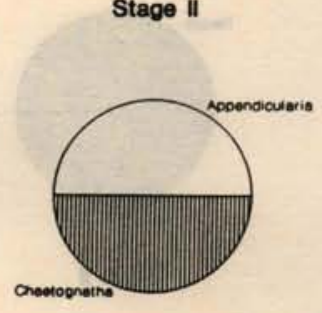

Stage IV

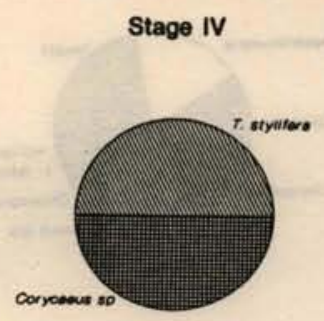

Fig. 5. Food items of S. friderici at each maturity stage. A - Winter 1987; B - Summer 1987. 
A

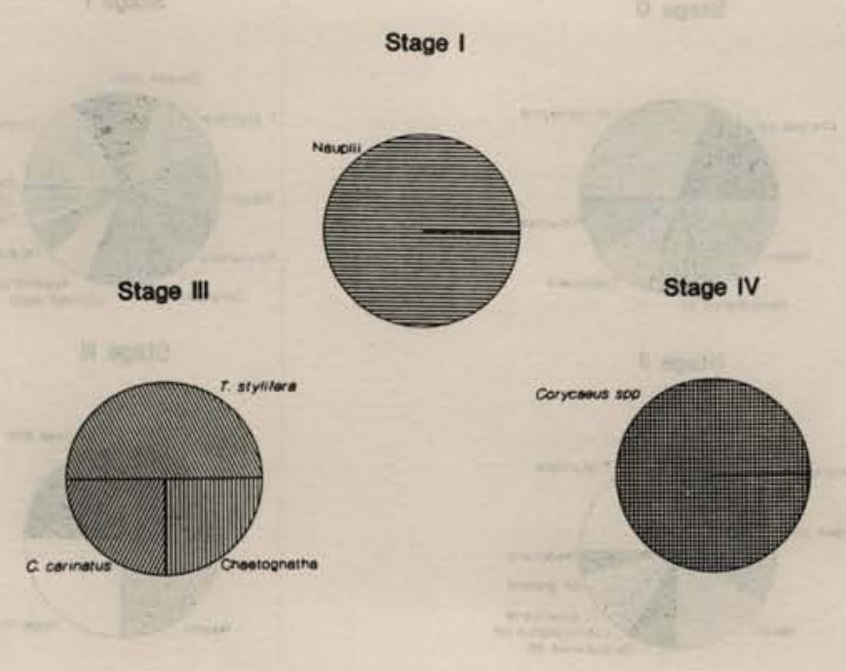

- B

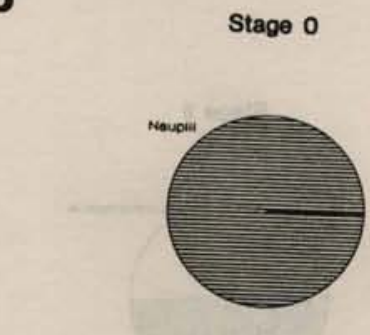

Stage \|

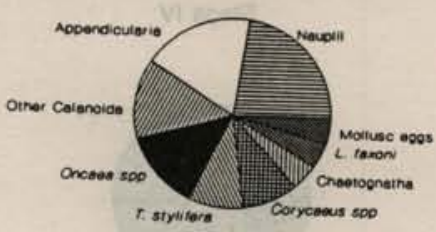

Stage I

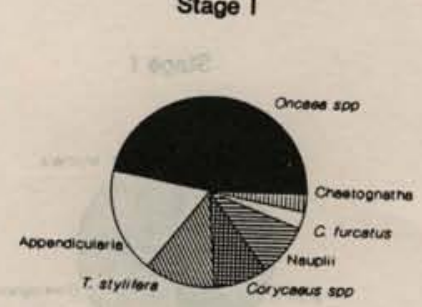

Stage III

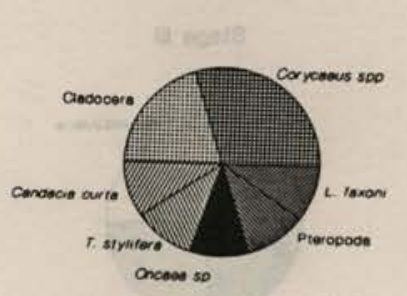

Fig. 6. Food items of S. hispida at each maturity stage. A - Summer 1985; B - Winter 1986. 
A
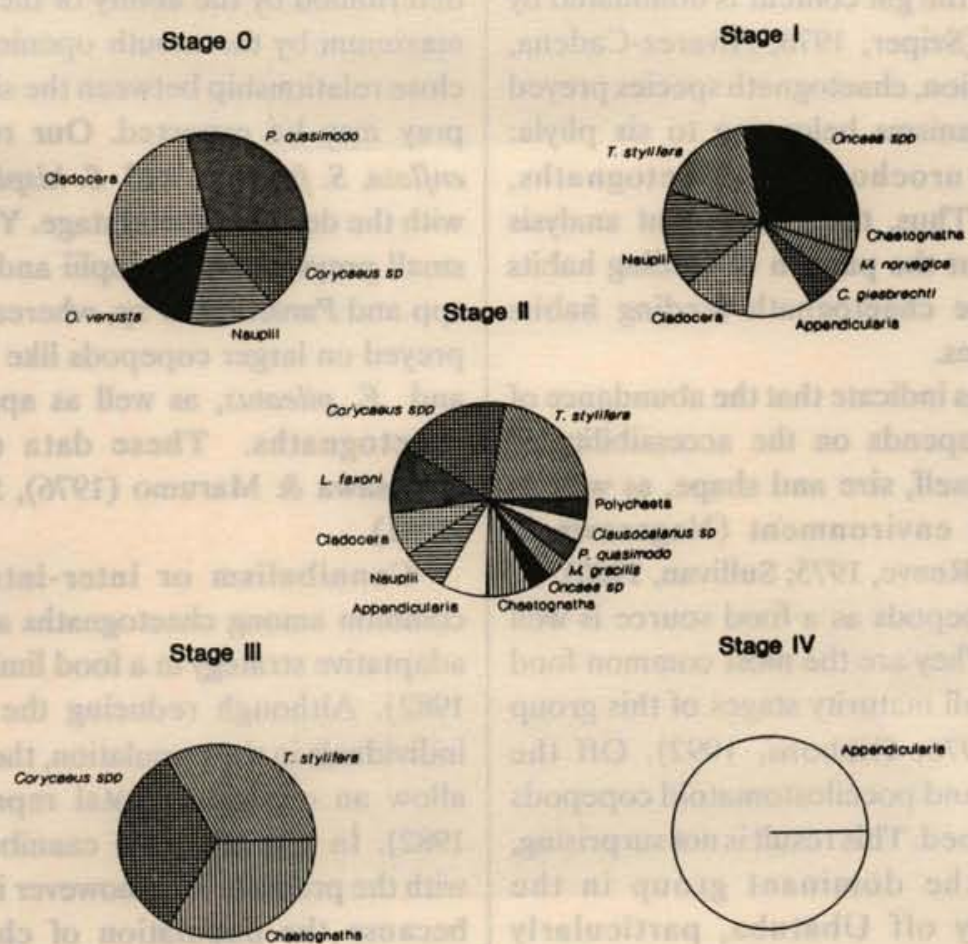

B

Stage

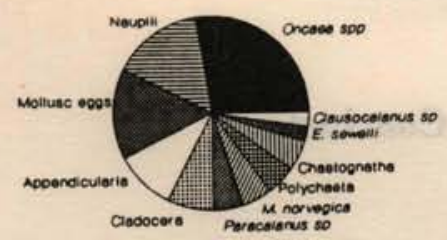

Stage III

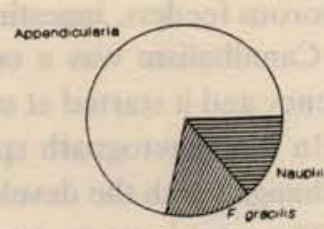

Stage II

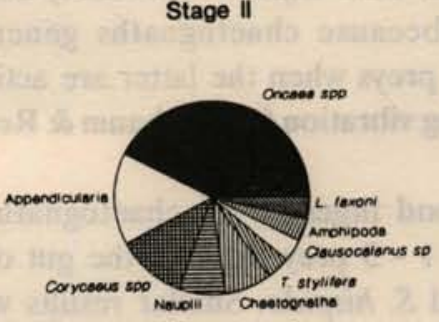

Fig. 7. Food items of S. hispida at each maturity stage. A - Summer 1986; B - Winter 1987. 


\section{Discussion}

Chaetognaths feed on a wide variety of food organisms (Alvariño, 1985), however the gut content is dominated by few zooplankton groups (Sziper, 1978; Alvarez-Cadena, 1993). Off the Ubatuba region, chaetognath species preyed on a wide variety of organisms belonging to six phyla: crustaceans, molluscs, urochordata, chaetognaths, annelids and cnidarians. Thus, the gut content analysis reported here, showed that the pattern of feeding habits correspond well with the chaetognath feeding habits reported from other regions.

Studies on chaetognaths indicate that the abundance of prey types in the diet depends on the accessibility or vulnerability of the prey itself, size and shape, as well as their abundance in the environment (Nagasawa \& Marumo, 1972; Cosper \& Reeve, 1975; Sullivan, 1980).

The importance of copepods as a food source is well known for chaetognaths. They are the most common food items found in the gut of all maturity stages of this group (Stone, 1969; Pearre, 1976; Gibbons, 1992). Off the Ubatuba region, calanoid and poecilostomatoid copepods were the preys most consumed. This result is not surprising, since copepods were the dominant group in the zooplankton community off Ubatuba, particularly Paracalanus quasimodo, Ctenocalanus heronae, C. vanus, T. stylifera, Oncaea curta, O. venusta and Corycaeus giesbrechti (Vega-Pérez, 1993). Thus, the food taken by chaetognaths is closely related to the abundance and specific composition of the copepods in the plankton (Rakusa-Suszczewski, 1969, Sullivan, 1980).

The presence of a considerable amount of mollusc eggs found in the gut content of $S$. enflata is probably due to accidental ingestion, because chaetognaths generally locate and attack their preys when the latter are actively swimming and producing vibration (Feigenbaum \& Reeve, 1977).

The quantity of food ingested by chaetognaths is variable. We observed $1-3$ prey items in the gut of $S$. enflata, $S$. friderici and $S$. hispida. Similar results were reported by Feigenbaum \& Marris (1984) and Stone (1969). According to these authors the guts contain typically just one prey, but multiple preys (2-3) can also be found.

A high number of chaetognaths is usually found with empty guts (Stone, 1969; Stuart \& Verheye, 1991). According to Pearre (1973) this is likely due to the hauls which capture them at depths where they do not necessarily feed. Oresland (1987) suggested that these predators often fail in catching their prey when the latter are in high concentration, because feeding is inhibited in high density of preys. We also found the presence of a considerable amount of empty guts. It may possibly reflect a great dependency on very digestible soft-bodied preys as annelids and larvaceans which were not found in the gut contents as suggested by Vega-Pérez \& Liang (1992).

The minimum size of the chaetognath prey is determined by the ability of the hooks to grasp it and the maximum by the mouth opening (Pearre, 1980). Thus, a close relationship between the size of the predator and the prey may be expected. Our results showed that, in $S$. enflata, $S$. friderici and $S$. hispida, the prey size changed with the developmental stage. Young stages fed heavily on small preys such as nauplii and small copepods Oncaea spp and Paracalanus sp, whereas the older stages (II-IV) preyed on larger copepods like $T$. stylifera, Corycaeus spp and E. pileatus, as well as appendicularians and other chaetognaths. These data confirm the results of Nagasawa \& Marumo (1976), Sziper (1978) and Pearre (1981).

Cannibalism or inter-intraspecific predation is common among chaetognaths and considered a valuable adaptative strategy in a food limited environment (Pearre, 1982). Although reducing the number of reproducing individuals in the population, the energetic advantage may allow an equivalent total reproductive effort (Pearre, 1982). In Ubatuba, the cannibalistic behavior increases with the predator size, however it is not frequent, probably because the population of chaetognaths is composed basically by young stages which tend to live more nearshore than the older stages. This distribution pattern may reduce the frequency of cannibalism (Oresland, 1987; Liang, 1993).

The data presented here suggest that the feeding patterns of chaetognaths are related to the zooplankton community structure. Further studies are necessary to understand the role of this group in the marine trophodynamics of the Brazilian tropical waters.

\section{Conclusions}

1. In Ubatuba region, chaetognaths showed a high number of specimens $(75,21 \%)$ with empty guts.

2. Sagitta enflata, $S$. friderici and $S$. hispida are carnivorous feeders, ingesting a high variety of prey items.

3. Cannibalism was a commom behavior, but in low frequency and it started at stage $I$.

4. In the chaetognath species studied, the size of the prey changed with the developmental stages.

5. The most important prey in the diet of $S$. enflata, $S$. friderici and $S$. hispida were calanoid and poecilostomatoid copepods.

6 . The diversity of preys consumed by the chaetognaths in Winter was higher than in Summer. 
7. The results obtained in this study suggest that the chaetognath predation on copepods can be intensive and it can even influence the structure of the copepod community.

\section{References}

ALMEIDA-PRADO, M. S. 1961a. Chaetognatha encontrados em águas brasileiras. Bolm Inst. oceanogr., S Paulo, 11(2):31-56.

1961b. Distribuição dos Chaetognatha no Atlântico Sul Ocidental. Bolm Inst. oceanogr., S Paulo, 11(4):15-49.

1968. Distribution and annual occurrence of Chaetognatha off Cananéia and Santos coast (São Paulo, Brazil). Bolm Inst. oceanogr., S Paulo, 17(1):33-55.

ALVAREZ-CADENA, J. N. 1993. Feeding of the chaetognath Sagitta elegans Verril. Estuar. coast. Shelf Sci., 36(2):195-206.

ALVARIÑO, A. 1985. Predation in the plankton realm, mainly with reference to fish larvae. Inv. Mar. CICIMAR, 2:1-122.

BOLTOVSKOY, D. 1981. Atlas del Atlántico Sudoccidental y métodos de trabajo con el zooplancton marino. Mar del Plata, INIDEP. 936p.

BUSKEY, E. J. 1993. Annual pattern of micro and mesozooplankton abundance and biomass in a subtropical estuary. J. Plankt. Res., 15(8):907-924.

CHENEY, J. 1985. Spatial and temporal patterns of oceanic chaetognaths in the western North Atlantic. II. Vertical distributon and migrations. Deep-Sea Res., 32:1061-1075.

COELHO, M. J. 1993. Zooplâncton do Atlântico sudoeste (2759'S a $39^{\circ} 59^{\prime} \mathrm{S} ; 44^{\circ} 52^{\prime} \mathrm{W}$ a $\left.56^{\circ} 56^{\prime} \mathrm{W}\right)$, com especial referência aos Chaetognatha. Dissertaçāo de Mestrado. Universidade de São Paulo, Instituto de Biociências. 183 p.

COSPER, T. C. \& REEVE, M. R. 1975. Digestive efficiency of the chaetognath Sagitta hispida Conant. J. expl mar. Biol. Ecol., 17:33-38.

FEIGENBAUM, D. L. \& MARRIS, R. C. 1984. Feeding in the Chaetognatha. Oceanogr. mar. Biol. a. Rev., 22:343-392.
FEI(iENBAUM, D. L. \& REEVE, M. R. 1977. Prey detection in the Chaetognatha: response to a vibration probe and experimental determination of attack distance in large aquaria. Limnol. Oceanogr., 22:1052-1058.

FERREIRA DA COSTA, P. 1970. Nota preliminar sobre ocorrência de Sagitta friderici e Sagitta enflata na Baía de Guanabara. Publcōes. Inst. Pesq. marin., Rio de Janeiro, 47:1-10.

GALLAGER, S. M. 1988. Visual observations of particle manipulation during feeding in larvae of a bivalve mollusc. Bull. mar. Sci., 43:344-365

GIBBONS, M. J. 1992. Diel feeding and vertical migration of Sagitta serratodentata Krohn tasmanica Thompson (Chaetognatha) in the southern Benguela. J. Plankt. Res., 14(2):249-260.

LIANG, T. H. 1993. Ocorrência e distribuição do filo Chaetognatha na região de Ubatuba, litoral norte do Estado de São Paulo. Dissertação de Mestrado. Universidade de São Paulo, Instituto Oceanográfico. 147 p.

NAGASAWA, S. \& MARUMO, R. 1972. Feeding of a pelagic Chaetognatha Sagitta nagae in Suruga Bay, Central Japan. J. oceanogr. Soc. Japan, 28:181-186.

$\&$ 1976. Further studies on the feeding habits of Sagitta nagae Alvariño in Suruga Bay, Central Japan. J. oceanogr.Soc. Japan., 32:209-218.

OMORI, M. \& IKEDA, T. 1984. Methods in marine zooplankton ecology. John Wiley. New York. 332 p.

ORESLAND, V. 1987. Feeding of the chaetognaths Sagitta elegans and $S$. setosa at different seasons in Gullmarsfjorden, Sweden. Mar. Ecol.-Progr. Ser., 39:69-79.

PEARRE Jr, S. 1973. Vertical migration and feeding in Sagitta elegans Verril. Ecology, 54:300-314.

1976. A seasonal study of the diet of three sympatric chaetognaths. Investigacion pesq., Barcelona, 40:1-16.

1980. Feeding by Chaetognatha: the relation of prey size to predator size in several species. Mar. Ecol.-Progr. Ser., 3:125-134. 
PEARRE Jr, S. 1981. Feeding by ('haetognatha: encrgy balance and importance of various components of the diet of Sagitta elegans. Mar. Ecol.-Progr. Ser., 5:45-54.

1982. Feeding by Chaetognatha: aspects of inter and intra specific predation. Mar. Ecol.-Progr. Ser., 7: 33-45.

RAKUSA-SUSZCZEWSKI, S. J. 1969. The food and feeding habits of Chaetognatha in the seas around the British Isles. Pol. Archs Hydrobiol., 16:213-232.

RAYMONT, T. E. 1983. Plankton and productivity in the oceans. Zooplankton. Oxford, Pergamon Press. v. 2.798 p.

REEVE, M. R. 1970. The biology of Chaetognatha. I. Quantitative aspects of growth and egg production in Sagitta hispida. In: Steele, J. H., ed. Marine food chains. Edinburgh, Oliver \& Boyed. p.169-189.

SCHOENER, T. W. 1968. The Anolis lizards of Bimini: resource partioning in a complex fauna. Ecology, 49:704-726.

STONE, J. H. 1969. The Chaetognatha community of the Agulhas Current, its structure and related properties. Ecol. Monogr., 39:433-463.

STUART, V. \& VERHEYE, H. M. 1991. Diel migration and feeding patterns of the chaetognath, Sagitta friderici, off the west coast of South Africa. J. mar. Res., 49:493-515.
SULLIVAN, B. K. 1980. In situ fecding behaviour of Sagitta elegans and Eukrohnia hamata (Chaetognatha) in relation to the vertical distributin and abundance of prey at Ocean Station "P". Limnol. Oceanogr., 25(2):317-326.

SZIPER, J. P. 1978. Feeding rate of the chaetognath Sagitta enflata in nature. Estuar. coast. mar.Sci., 7:567-575.

VANNUCI, M. \& HOSOE, K. 1952. Resultados científicos do cruzeiro do "Baependi" e do "Vega" a I. da Trindade Chaetognatha. Bolm Inst. oceanogr., S Paulo, 3(1-2):1-31.

VEGA-PÉREZ, L. A. 1993. Estudo do zooplâncton da regiāo de Ubatuba, Estado de São Paulo. Publção esp. Inst. oceanogr., S Paulo, 10:65-84.

\& LIANG, T. H. 1992. Feeding

of a pelagic chaetognath, Sagitta friderici Ritter-Zahony off Ubatuba region (São Paulo, Brazil). Bolm Inst. oceanogr., S Paulo, 40(1/2):93100.

WALLACE Jr, R.K. 1981. An assesment of diet overlap indexes. Trans. Am. Fish. Soc., 110:72-76.

ZARET, T. M. \& RAND, A. S. 1971. Competition in tropical stream fishes: support for the competitive exclusion principle. Ecology, 52:336-342. 